\title{
TRAINING OF TRAINER BAGI MAHASISWA KKN TENTANG PEMANFAATAN LIMBAH KAIN DALAM RANGKA PEMBERDAYAAN MASYARAKAT
}

\author{
Etin Solihatin"), Desfrina ${ }^{2)}$, Adi Wijanarko ${ }^{3)}$ \\ Fakultas Ilmu Sosial Universitas Negeri Jakarta
}

\begin{abstract}
ABSTRAK
TOT pemanfaatan limbah kain menjadi aksesoris dalam rangka pemberdayaan masyarakat dilaksanakan di ruang perlengkapan yang berbatasan dengan LPM dilaksanakan pada tanggal 26 Juni 2015. Diikuti oleh 21 mahasiswa KKN yang akan melaksanakan KKN tanggal 27 Juli 2015 - 26 Agustus 2015.

Hasil Pengabdian Masyarakat ini yaitu TOT merupakan sarana yang efektif untuk memberikan informasi, sekaligus mempraktekkan/melatih mereka memanfaatkan limbah kain menjadi asesoris yang baik dan bernilai ekonomis. Disamping itu tanggung jawab Perguruan Tinggi dalam Tri Dharma Perguruan tinggi dapat terealisasi dengan baik.
\end{abstract}

Kata Kunci : Limbah kain, Pemberdayaan Masyarakat

\section{PENDAHULUAN}

A. Analisis Situasi

Dalam kegiatan KKN mahasiswa perlu dibekali dengan berbagai keterampilan, di luar keahlian/ilmu yang sesuai program studinya. Hal ini diharapkan agar kemampuan yang dimiliki mahasiswa KKN relatif "mumpuni”, sehingga mereka adaptif dan mampu mencari solusi, jika ditemukan masalah di lapangan (lokasi KKN).

Namun program pembekalan mahasiswa KKN tidak diberi dana lagi oleh BOPTN. Untuk mengatasi kekurangan ini, maka beberapa program "Pengabdian Masyarakat Dosen” dihimbau agar ada yang difokuskan kepada mahasiswa, ada juga tetap langsung diberikan kepada masyarakat.

Program "Pengabdian Masyarakat Dosen” difokuskan kepada mahasiswa, berupa melatih mahasiswa KKN, untuk selanjutnya mahasiswa wajib mengajar-kan kembali kepada masyarakat. Hal ini dimaksudkan agar masyarakat dalam hal ini ibu-ibu dan remaja putri memiliki keahlian, sehingga budaya wirausaha dapat terwujud.

Berdasarkan hasil survey di lokasi KKN banyak ditemukan limbah kain dari para penjahit yang berakhir di pembakaran sampah. Padahal kalau punya sedikit keahlian dan kemampuan limbah kain itu dapat dijadikan asesoris yang menghasilkan uang, sebagai sumber pendapatan tambahan.

Untuk itu tim "Pengabdian Masyarakat Dosen”, ingin mengubah "sampah kain" menjadi "barang yang bermanfaat dan bernilai jual”. Dengan demikian perlu melatih mahasiswa melalui program TOT, diharapkan mahasiswa dapat mengajarkan kembali kepada masyarakat, di mana mahasiswa ditempatkan.

\section{B. Perumusan Masalah}

Berdasarkan analisis situasi di atas, maka masalah dalam kegiatan ini dirumuskan sebagai berikut: "Bagaimana memanfaatkan limbah kain melalui training of trainer mahasiswa KKN dalam rangka pemberdayaan masyarakat?”. 


\section{Tujuan Kegiatan}

Kegiatan pengabdian Masyarakat ini memiliki tujuan sebagai berikut:

1. Meningkatkan pengetahuan dan keterampilan bagi mahasiswa KKN mengenai pemanfaatan limbah kain untuk dijadikan asesoris yang bermanfaat dan bernilai ekonomis.

2. Memberi solusi dalam mengatasi limbah kain dari para penjahit, sehingga menjadi bahan baku produksi asesoris.

3. Melatih calon trainer (mahasiswa $\mathrm{KKN}$ ) pembuatan asesoris dari bahan limbah kain.

\section{Manfaat Kegiatan}

Adapun manfaat pengabdian masyarakat yaitu :

1. Adanya peningkatan keterampilan mahasiswa di luar bidang keahlian (sesuai prodi), saat pelaksanaan KKN

2. Dengan pelatihan ini mengatasi masalah limbah kain di lokasi KKN menjadi barang ekonomis.

\section{KAJIAN PUSTAKA}

\section{A. Asesoris dari Limbah Kain}

Menurut Wasia Rusbani (1984:193) pelengkap busana berdasarkan fungsinya dibagi menjadi dua macam yaitu: pelengkap busana praktis dinamakan millineries dan pelengkap buana estetis yang dinamakan aksesoris. Millineries adalah pelengkap busana yang memiliki fungsi yaitu sebagai penambah keindahan dan fungsi lain yang berguna bagi si pemakai. Aksesoris adalah pelengkap busana yang berfungsi sebagai penambah keindahan si pemakai dalam berbusana. Aksesoris ada yang tergolong tradisional dan ada yang tergolong modern atau populer.

Aksesoris yang tergolong modern yaitu yang dibuat dari bermacam-macam bahan, banyak terdapat di pasaran, dan pemakainya dalam mengenakan tidak terikat waktu serta kesempatan. Bahan yang dipergunakan untuk membuat aksesoris pelengkap busana beraneka ragam, seperti kain, plastik, gelas, kerang, kulit, kayu dan lain sebagainya.

Aksesoris dapat menghasilkan begitu banyak gaya yang membuat penampilan berbeda-beda, dan mem-berikan gaya yang istimewa meskipun dengan busana sederhana. Aksesoris secara otomatis akan menarik perhatian, sekaligus menciptakan penampilan yang memberi kesan menarik. Sebaiknya pemakaian aksesoris disesuaikan dengan bentuk badan dan busana yang dikenakan.

Menurut Khairuddin (2002 : 4) keluarga adalah kelompok primer yang terpenting dalam masyarakat. Suatu keluarga terdiri atas sekumpulan orang yang hidup bersama untuk jangka waktu selama mungkin, jika mungkin untuk selamanya.

Adapun peranan ibu rumah tangga dan para remaja di dalam keluarganya mempunyai kedudukan yang sangat penting. Ferber dan Birbaun dalam Totok Mardianto (2005: 90) mengatakan bahwa ibu rumah tangga dan para remaja adalah orang yang dapat berperan dalam membantu mengurus segala sesuatu dalam keluarga.

Banyak ibu rumah tangga dan para remaja di pedesaan yang menganggap bahwa tugas utama seorang ibu membantu suami, mem-bimbing dan mengasuh anak. Padahal tugas dan tanggung jawab mereka sebenarnya bisa lebih dari itu. Mereka dapat menambah ilmu pengetahuan dan keterampilan secara terus menerus, dapat membantu meningkatkan pereko-nomian keluarga dengan berlatih dan berwirausaha tanpa meninggalkan peranannya sebagai ibu rumah tangga, dan para remaja yang baik.

Para ibu rumah tangga dan para remaja putri inilah yang akan dijadikan sasaran atau peserta pelatihan oleh mahasiswa KKN yang sudah lulus pada "Pelatihan calon pelatih aksesoris dan limbah kain” di lokasi KKN. 


\section{METODE PELAKSANAAN}

\section{A. Metode Pemecahan Masalah}

Agar pelatihan calon pelatih (TOT) tentang pemanfaatan limbah kain dalam rangka pemberdayaan masyarakat berjalan dengan baik, harus melalui tahapan:

1. Memberikan "informasi penting" berkaitan dengan pembuatan asesoris dari limbah kain

2. Praktek pembuatan asesoris secara bersama-sama dan tetap didampingi instruktur (dosen)

3. Selama proses "praktek pembuatan asesoris" mahasiswa KKN boleh bertanya yang berkaitan dengan materi yang sedang dipraktekkan.

4. teknik "mengemas" hasil produksi asesoris, agar bagus dan mutu terjamin

5. Memberikan "informasi tentang teknik pemasaran (menjual produk)”.

\section{B. Kerangka Pemecahan Masalah}

Salah satu upaya yang dapat dilaksanakan dalam rangka peme-cahan masalah "limbah kain” di lokasi KKN berdasarkan hasil survey awal, yaitu melalui pelatihan calon pelatih pembuat asesoris dari limbah kain, dilakukan dengan tahapan sebagai berikut :

1. Mengadakan koordinasi dengan pihak terkait yaitu pihak LPM dan mahasiswa KKN

2. Menyusun jadwal kegiatan pelatihan calon pelatih pembuat asesoris dari limbah kain

3. Menggandakan materi power point untuk peserta pelatihan

4. Melaksanakan program "pelatihan calon pelatih asesoris dari limbah kain”, mulai dari persiapan, pengumpulan bahan-bahan, praktek membuat, praktek mengemas, dan praktek memasarkan.

5. Melakukan evaluasi program dan penyusunan laporan

\section{Khalayak Sasaran}

Khalayak sasaran yang dianggap strategis yaitu mahasiswa KKN untuk dilibatkan dalam pelatihan calon pelatih pembuat asesoris dari limbah kain.

\section{Tempat dan Waktu Kegiatan}

Kegiatan pelatihan ini dilak-sanakan di Ruang Perlengkapan Universitas Negeri Jakarta yang berbatasan dengan LPM. Waktu kegiatan tanggal 26 Juni 2015, hari Jum'at, pukul 10.00 WIB sampai selesai.

\section{PELAKSANAAN KEGIATAN}

\section{A. Realisasi Pemecahan Masalah}

Berdasarkan masalah sebagaimana yang diuraikan di atas, maka langkah pemecahan masalah dilaksanakan sebagai berikut :

1. Mengadakan koordinasi dengan pihakpihak terkait:

a. Mengurus perizinan tempat (di ruang perlengkapan UNJ, yang berbatasan dengan ruang LPM)

b. Narasumber TOT tentang pemanfaatan limbah kain dalam rangka pemberdayaan masyarakat dari Tim Pengabdian Masyarakat

2. Menyusun agenda atau susunan acara, sehingga ditetapkan pada hari Jum'at tanggal 26 Juni 2015, mulai pukul 10.00 WIB sampai selesai.

\section{B. Sasaran}

Peserta yang mengikuti pelatihan TOT pemanfaatan limbah kain dalam rangka pemberdayaan masyarakat, sebanyak 21 mahasiswa yang akan mengikuti KKN tahap II yaitu tanggal 27 Juli 2017 - 26 Agustus 2015.

\section{Keterkaitan}

Program pelatihan ini bersifat terpadu, maka banyak pihak yang terkait dalam kegiatan ini yaitu: 
Narasumber pelatihan dari Dosen Teknik Prodi Tata Busana, dibantu oleh Dosen Fakultas Ilmu Sosial Program Studi PPKN.

Sedangkan mahasiswa KKN yang direkrut dari berbagai kelompok, dengan lokasi KKN yang berbeda-beda. 3 orang mahasiswa PAUD, yang akan KKN di lokasi Kecamatan Ciasem Kabupaten Subang. Lainnya dari kelompok KKN di Kecamatan Cinangka dengan 14 desa.

\section{Metode}

Untuk mensukseskan program TOT ini, metode yang digunakan adalah praktek dan partisipasi aktif dengan melalui tahapan: (1) pemberian informasi dengan power point dan print out yang dibagikan. Metode ini penting untuk menyampaikan informasi-informasi penting berkaitan dengan pemanfaatan limbah kain menjadi aksesoris, (2) tanya jawab yang dilaksanakan secara aktif oleh seluruh peserta, (3) praktek pembuatan asesoris dan limbah kain.

\section{HASIL KEGIATAN}

\section{A. Hasil Kegiatan}

Hasil kegiatan dari TOT pemanfaatan limbah kain menjadi asesoris dalam rangka pemberdayaan masyarakat, diantaranya :

1. Mahasiswa peserta KKN dapat membuat asesoris dari pemanfaatan limbah kain, sehingga saat di lapangan nanti dapat mengajarkan kembali kepada ibu-ibu dan remaja putri. Untuk meningkatkan pen-dapatan mereka dengan memanfaat-kan limbah kain menjadi barang yang bernilai ekonomis. Saat KKN di lapangan mahasiswa TOT ini akan terus dipantau untuk ketuntasan program TOT ini. Dengan demikian keber-hasilannya dapat dievaluasi dengan baik. Saat TOT telah berhasil, maka dapat membuat asesoris dengan praktek langsung membuatnya. Lebih lengkapnya foto-foto kegiatan akan ditampilkan pada lampiran.

2. Terjadinya sikap positif terhadap limbah kain yang biasanya dibuang, ternyata dapat dijadikan asesoris yang bagus dan bernilai jual.

3. Meningkatkan kemampuan dan rasa senang terhadap "hal yang dianggap baru”, karena dipraktek-kan dan hasilnya boleh dibawa pulang.

\section{B. Hasil Evaluasi}

Hasil evaluasi dilakukan terhadap "produk" yang dibuat mahasiswa KKN. Disamping itu minat dan antusias peserta TOT, meskipun puasa mereka tetap semangat, dan meninginkan program dilanjutkan.

\section{KESIMPULAN}

Setelah dilakukan kegiatan Pengabdian pada Masyarakat ini, melalui TOT dapat disimpulkan bahwa:

TOT merupakan sarana yang efektif untuk memberikan informasi, sekaligus mempraktekan/melatih mereka memanfaatkan limbah kain menjadi asesoris dalam rangka pemberdayaan masyarakat.

Disamping itu tanggung jawab Perguruan Tinggi dalam Tri Dharma Perguruan Tinggi dapat terealisasi dengan baik.

\section{DAFTAR PUSTAKA}

Budiman, Yoyok dan Kusumawardhani, Reni. 2002. Anda dan Gaya Busana. Jakarta: Gramedia Pustaka Utama.

Hardiana, Iva. 2013. Terampil Membuat Asesoris. Jakarta: Gramedia Pustaka.

Khairudin. 2002. Sosiologi Keluarga. Yogyakarta: Liberti

Rusbani, Waria dan Soerjaatmadja, Rosmini. 1984. Pengetahuan Pakaian. Jakarta: Depdiknas Dirjen Pendidikan Dasar dan Menengah. 